\title{
Relation of alveolar size to forced vital capacity in professional divers
}

\author{
I M CALDER, ${ }^{1}$ K SWEETNHAM, ${ }^{1} \mathrm{~K} \mathrm{~K} \mathrm{CHAN,}{ }^{1}$ M M R WILliAMS ${ }^{2}$ \\ From the Institute of Pathology, ${ }^{1}$ The London Hospital, London E1 1BB, and Department of Nuclear \\ Engineering, ${ }^{2}$ Queen Mary College, London E1,UK
}

\begin{abstract}
Eight cases have been studied in which both lung function and histological morphometric data was available on divers' lungs. A correlation was found between the increase in forced vital capacity measured at routine annual medical examination and the morphometric measurement of alveoli by mean cord length. The results suggest that reduction of forced expiratory volume in one second may be due to narrowing of small airways by distention of the alveoli.
\end{abstract}

The effects of a hyperbaric environment have long been recognised in certain target organs especially bone $^{1}$ and the spinal cord. ${ }^{2}$ It is becoming increasingly apparent, however, that the effects are total body and multiorgan, of which only some may be clinically detectable. Lung function tests, using a Vitalograph, form part of routine diving medical examinations and vital capacity has been shown to be one of the parameters that increase. It has been suggested that this change may be due to increase in accessory respiratory muscle, development of more lung units, or narrowing of airways due to loss of lung elastic tissue. ${ }^{3}$

It has been possible to establish a relation between vital capacity and alveolar size by a comparison of clinical and histological data.

\section{Materials and methods}

In a series of necropsies on professional divers 37 cases were suitable for detailed examination of the lungs. Of these, it was possible to obtain the details of the clinical history, including lung function, in only eight. These have been used as the basis of the present study and the data, together with causes of death, are recorded in table 1 .

\section{LUNG MORPHOMETRY}

All the lungs were inflated through the trachea at a standard pressure of $25-30 \mathrm{~cm}$ water from $10 \%$ formal saline using the technique described by Heard et al. ${ }^{4}$ As part of the routine necropsy protocol the fixed lungs were sliced into sections about $1.5 \mathrm{~cm}$ Accepted 29 September 1986 thick by the method of Kleinerman and Cowdrey. ${ }^{5}$ Whole lung sections were randomly selected from each of the eight cases and laid flat. On the upper cut surface of the slice a transparent plastic sheet was laid on which was superimposed a rectangular lattice $1.5 \times 2.5 \mathrm{~cm}$, a method employed by Weibel. ${ }^{6}$ Each field was numbered consecutively and continuously over all the slices and the fields for sampling were selected by a method of random numbers. This fixed the location of the blocks which were marked on the lung tissue by inserting headless pins through the perforated corners of the squares. The blocks were paraffin wax embedded, cut at 5-7 $\mu \mathrm{m}$, and stained with retriculin.

The histological preparations were examined through a Vickers binocular microscope, fitted with an image splitter, that was coupled to a Cambridge Instruments model 720 Quantimet image analysis system. This gave a display of the histological image on a monitor screen and allowed the electronic image to be definitively identified by independent observation through the light microscope. An electronic pencil allowed each alveolus to be accurately outlined. The quantimet program could then resolve from the area of the individual alveoli the mean cord length. The machine was calibrated to resolve this into micrometres.

The field of the sections were examined by blind random displacement of the mechanical stage without observing through the tube. To eliminate bias the horizontal and vertical stage micrometers were set each time at an integer millimetre position. This procedure was repeated until 100 alveoli had been counted. 


\begin{tabular}{|c|c|c|c|c|c|c|c|c|}
\hline $\begin{array}{l}\text { Case } \\
\text { No }\end{array}$ & Age & $F V C$ & ${ }^{3} / F V C$ & $\begin{array}{l}\text { Period } \\
\text { between } \\
\text { medical exam } \\
\text { and death } \\
\text { (months) }\end{array}$ & $\begin{array}{l}\text { Years of } \\
\text { experience } \\
\text { in diving }\end{array}$ & $\begin{array}{l}\text { Greatest } \\
\text { depth } \\
\text { dived }(m)\end{array}$ & Cause of death & $\begin{array}{l}\text { Interval betwe } \\
\text { death and } \\
\text { necropsy }(h)\end{array}$ \\
\hline $\begin{array}{l}1 \\
2 \\
3 \\
4 \\
5 \\
6 \\
7 \\
8\end{array}$ & $\begin{array}{l}25 \\
23 \\
28 \\
33 \\
28 \\
31 \\
26 \\
31\end{array}$ & $\begin{array}{r}74 \\
123 \\
79 \\
131 \\
125 \\
147 \\
106 \\
113\end{array}$ & $\begin{array}{l}4 \cdot 2 \\
4 \cdot 97 \\
4 \cdot 29 \\
5 \cdot 08 \\
5 \cdot 0 \\
5 \cdot 28 \\
4 \cdot 73 \\
4 \cdot 83\end{array}$ & $\begin{array}{l}6 \\
1 \\
4 \\
8 \\
6 \\
4 \\
5 \\
8\end{array}$ & $\begin{array}{r}5 \\
2 \\
9 \\
14 \\
8 \\
8 \\
6 \\
12\end{array}$ & $\begin{array}{r}50 \\
100 \\
50 \\
150 \\
185 \\
200 \\
50 \\
150\end{array}$ & $\begin{array}{l}\text { Hypothermia } \\
\text { Head injury } \\
\text { Acute anoxia } \\
\text { Hypothermia } \\
\text { Asphyxia (drowning) } \\
\text { Asphyxia (drowning) } \\
\text { Acute anoxia } \\
\text { Asphyxia (drowning) }\end{array}$ & $\begin{array}{l}36 \\
24 \\
12 \\
48 \\
36 \\
24 \\
18 \\
24\end{array}$ \\
\hline
\end{tabular}

Table 2 Quantimet results

\begin{tabular}{|c|c|c|c|c|c|c|}
\hline Case No & $M C L(\mu)$ & Standard deviation & Alveoli per field & Alveoli counted & No of fields & Standard errora \\
\hline $\begin{array}{l}1 \\
2 \\
3 \\
4 \\
5 \\
6 \\
7 \\
8\end{array}$ & $\begin{array}{l}184 \cdot 9 \\
218 \cdot 3 \\
184 \cdot 8 \\
222 \cdot 7 \\
218 \cdot 9 \\
231 \cdot 2 \\
167 \cdot 1 \\
212 \cdot 3\end{array}$ & $\begin{array}{l}97 \cdot 59 \\
63 \cdot 59 \\
59 \cdot 28 \\
71 \cdot 75 \\
74 \cdot 88 \\
65 \cdot 85 \\
65 \cdot 17 \\
85 \cdot 85\end{array}$ & $\begin{array}{r}17 \\
10 \\
25 \\
9 \\
21 \\
16 \\
21 \\
11\end{array}$ & $\begin{array}{l}107 \\
105 \\
100 \\
107 \\
104 \\
110 \\
101 \\
101\end{array}$ & $\begin{array}{r}7 \\
11 \\
4 \\
11 \\
5 \\
7 \\
5 \\
10\end{array}$ & $\begin{array}{l}9.42 \\
6.21 \\
5.93 \\
6.24 \\
4.56 \\
6.24 \\
6.49 \\
6.54\end{array}$ \\
\hline
\end{tabular}

FORCED VITAL CAPACITY (FVC)

Forced vital capacity is one of the parameters required as part of the annual medical examination under the "Diving Operations at Work Regulations." This had been measured in all cases using an $\mathbf{R}$ Model Vitalograph and had been repeated at least twice to obtain reproducible tracings.

\section{Results}

\section{QUANTIMETRIC MEASUREMENT}

The Quantimetric 720 was programmed to print out

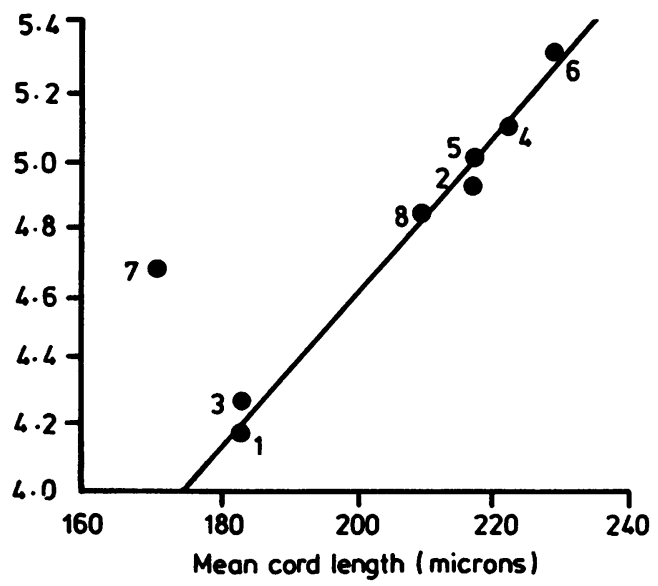

Forced vital capacity plotted against mean cord length. Aberrant case 7 is only smoker in series. mean cord length, standard deviation, alveoli pex field, number of alveoli counted, number of fields and standard error (table 2).

FORCED VITAL CAPACITY

The FVC measurements were abstracted from thă clinical records and checked against the available Vitalograph flow charts. The FVC and ${ }^{3} / \mathrm{FVC}$ inte $\overrightarrow{0}$ val between medical and death, years of diving exper $\bar{B}$ ence, and greatest depth of diving are shown i table 1.

The $3 /$ FVC were plotted against the mean cord length on linear scale, shown in the figure.

\section{Discussion}

Morphometry with respect to lung has been exten sively exploited by several workers. ${ }^{689}$ The presen study is the first in which it has been possible to coms pare accurate clinical and specially prepared histologe. ical data in human subjects.

Considerable attention has been paid to lung funetion in commercial divers. ${ }^{310}$ Clinical evidence b. these groups of workers has shown that a significanto association exists between the maximal depth the sub jects had experienced and FVC, but independent of age, stature, and smoking habits. There is, however some evidence from these workers that the ratio of forced expiratory volume in one second $\left(\mathrm{FEV}_{1}\right)$ tō FVC was reduced, suggesting that there was narrow ing of airways secondary to diving induced loss o̊ elastic tissue. Morphometric evidence considered her: 
suggests that the changes of FVC are related to an increase in alveolar volume.

The rationale for measuring the MCL as an overall reflection of increase in alveolar volume is based on the well established theoretical consideration of Crofton. ${ }^{11}$ The principle of MCL is simple and reliable in application and does not depend on any geometrical pattern of the system. This is an important consideration in view of the concept that the shape of the alveolus is a complex of a double cone and a dodecahedron.

In the past some investigators had used questionable methods for determining mean cord length but those of Tomkeiff ${ }^{9}$ and Hennig ${ }^{8}$ are considered to be the most reliable. This basic principle was exploited by using the Quantimet 720 . Kulenkampff attributed errors to poor fixation methods, which allowed uneven distention as formalin was inserted while the lungs were still in the cadaver. ${ }^{12}$

The well established inflation technique ${ }^{4}$ meant that all the lungs carefully dissected from cadavers were inflated at a pressure of $25-30 \mathrm{~cm}$ water. The actual measurements shown in table 2 agree with the results of other experimental workers, which range from that of $254 \mu \mathrm{m}^{13}$ to the more recent figures of $250-300 \mu \mathrm{m}^{14} 15$

Although these figures are slightly higher than those of the present series there is little information on the methods used to inflate the lungs; these could have caused overdistention. The present cases were all inflated at the same pressure and could therefore be considered as comparable. There was also a set but random protocol for sampling the lungs.

All the measurements of FVC were made within eight months of death and should give a reasonable reflection of the value at this time. The one aberrant result is for case No 7 who was the only smoker in the series ( 25 cigarettes a day).

In a different dimension there is some correlation between FVC and the greatest depth dived which is in accord with earlier observers. ${ }^{6}$ Years of experience in diving did not relate to FVC changes.

Examination of the curve of the graph in this series shows that the increase in vital capacities is closely related to the increase in mean cord length which in turn reflects the alveolar volume. This lends support to the supposition that in this particular group of divers there is an actual increase in alveolar size and it is not merely due to an increase in accessory respiratory muscle power giving a physiological effect.

It has to be considered that the distention of alveoli may be locally at the expense of small airways. As a result, the airways may be narrowed by the outside physical pressure of the distended alveoli, which is reflected in the reduction of the $\mathrm{FEV}_{1} .{ }^{10}$
We thank Commander Warner, HM Inspector Diving, Department of Energy, North Sea Medical Centre, Great Yarmouth, for help in retrieving the clinical data and also Dr M Dunnill, Department of Histopathology, John Radcliffe Hospital, Oxford, and Dr JE Coates of the Respiration \& Exercise Laboratory, Department of Occupational Health and Hygiene, University of Newcastle upon Tyne, and Mr John Sheppard of Cambridge Instruments for their constructive criticism and advice. We also thank Her Majesty's Coroners for their co-operation in arranging necropsies and Mrs E Williams for her secretarial help.

\section{References}

1 Twynam EG. Pathological changes of aseptic necrosis. Br Med J 1888;31:190-1.

2 Boycott AE, Damant GCC, Haldane JS. The prevention of compressed air illness. J Hyg 1908;8:342-443.

3 Davey IS, Cotes JE, Reid JW. Relationship of ventrilatory capacity to hyperbaric exposure in divers. J Appl Physiol 1984;56:1665-8.

4 Heard B, Esterly JR, Wootliffe JS. A modified apparatus for fixing lungs to study the pathology of emphysema. Am Rev Respir Dis 1967;95:311-2.

5 Kleinerman J, Cowdrey CR. The thick section technique for the study of respiratory pathology. Am Rev Respir Dis 1964;89:206-13.

6 Weibel ER. Morphometry of the human lung. Berlin: Springer-Verlag, 1963:47-8.

7 Diving operations at work regulations section 13(i)(a). London: HMSO, 1981.

8 Hennig A. Diskussion der Fehler bei der Volumenbestimmung microskopisch kleiner kórper oder Hohlraume aus den Schnittpiojektionen. Zeitschrift fur wissenschaftliche Mikroskopie und microskopische Technik Stuttgart 1956;63:67-71.

9 Tomkeiff SE. Linear intercepts, areas and volumes. Nature 1945:155.

10 Crosbie WA, Clarke MB, Cox RAF, et al. Physical characteristics and ventilatory function of $\mathbf{4 0 4}$ commercial divers working in the North Sea. Br J Ind Med 1977;34:19-25.

11 Crofton MW. On the theory of local probability, applied to straight lines drawn at random in a plane; the methods used being also extended to the proof of certain new theorems in the integral calculus. Philos Trans Soc Lond 1898;158:181-4.

12 Kulenkampff $\mathrm{H}$. Bestimmung der inneven Oberfache einer menschlichen Lunge. Zeitschrift füs Anatomie Entwickle Gesch 1977;120:198-200.

13 Hales S. Haemastaticks. London, 1733.

14 Baak JPA, Oort J. A manual of morphometry in diagnostic pathology. Berlin: Springer-Verlag, 1983:133.

15 Bates DV, Macklem PT, Christie RV. Respiratory function in disease. Philadelphia: WB Saunders \& Co, 1973:24. 